\title{
PERSEPSI MAHASISWA PENDIDIKAN MATEMATIKA TERHADAP KINERJA DOSEN DALAM PROSES PERKULIAHAN
}

\section{PERCEPTION OF MATHEMATICS EDUCATION STUDENTS ON THE PERFORMANCE OF LECTURERS DURING LECTURER PROCESS}

\author{
Nani Kurniati*, Baidowi, Nurul Hikmah \\ Program Studi Pendidikan Matematika, Fakultas Keguruan dan Ilmu Pendidikan, Universitas Mataram \\ Jalan Majapahit 62 Mataram, 83125, Lombok, Indonesia \\ *Email: nanikurniati@unram.ac.id
}

Diterima: 05 Januari 2018. Disetujui: 26 Maret 2018. Dipublikasikan: 31 Maret 2018

\begin{abstract}
Abstrak: Penelitian ini bertujuan untuk mengetahui persepsi mahasiswa pendidikan matematika terhadap kinerja dosen dalam proses perkuliahan dan untuk mengetahui hal-hal yang perlu diperbaiki maupun dikembangkan dalam proses perkuliahan berdasarkan persepsi mahasiswa terhadap kinerja dosen dalam proses perkuliahan tahun akademik 2015/2016. Untuk mencapai tujuan tersebut peneltian ini dilakukan dengan metode penelitian deskriptif, untuk pengambilan data dilakukan melalui penyebaran angket, dengan populasi mahasiswa pendidikan matematika yang aktif pada tahun akademik 2015/2016. Instrumen yang digunakan dalam penelitian ini adalah sebuah angket tertutup, dimana responden tinggal memilih jawaban yang sudah tersedia. Hasil penelitian menunjukkan bahwa persepsi mahasiswa Program Studi Pendidikan Matematika FKIP Universitas Mataram terhadap kinerja dosen berkategori baik dengan prosentase skor $69,50 \%$. Artinya lebih dari $50 \%$ dan kurang dari atau sama dengan $75 \%$ dari jumlah dosen yang aktif di Program Studi Pendidikan Matematika FKIP Unram sudah melaksanakan proses perkuliahan dengan baik. Berdasarkan hasil prosentase skor untuk setiap indikator kinerja menurut persepsi mahasiswa ada beberapa hal yang harus dipertahankan dan dikembangkan oleh dosen yaitu 1). Memberikan apersepsi diawal perkuliahan yaitu dosen menjelaskan kaitan materi sebelumnya dengan materi yang akan dipelajari. 2). Dosen menggunakan metode mengajar yang bervariasi dalam pekuliahan. 3). Dosen memberi kesempatan kepada mahasiswa untuk bertanya mengenai materi yang belum dipahami. 4). Dosen memberikan tugas yang sesuai dengan materi yang telah diajarkan. 5). Dosen memberikan tambahan nilai bagi mahasiswa atau kelompok yang mampu menyelesaikan tugas dengan baik. 6). Dosen menyusun soal ujian sesuai dengan materi yang telah diajarkan. 7). Dosen menhargai pendapat atau jawaban mahasiswa meskipun dipandang kurang tepat. 8). Dosen bersikap obyektif dalam penilaian, dan 9). Dosen dapat dijadikan contoh baik sikap maupun prilaku. Namun ada juga beberapa hal yang harus diperbaiki yaitu masih banyak dosen yang tidak membagikan hasil ujian kepada mahasiswa, dosen tidak membahas soal ujian, dan dosen tidak mengadakan remedial untuk mahasiswa yang belum tuntas.
\end{abstract}

Kata kunci: persepsi, mahasiswa, kinerja, dosen

\begin{abstract}
This study aims to determine the perception of mathematics education students on the performance of lecturers, and to evaluate aspects that need to be improved and developed in the lecture process based on student perceptions of lecturer's performance in the academic year 2015/2016. This research is conducted by descriptive research method. Data was collected by questionnaires toward the population of active mathematics students. Closed questionnaire was applied as instrument whereas respondents just choose the answers that are already available. The results show that the perception of students of mathematics education FKIP Mataram University on the performance of their lecturers is categorized "good" with the percentage score of $69.5 \%$. This means that more than $50 \%$ and less than or equal to $75 \%$ of the number of active lecturers in the mathematics education FKIP Mataram University has done the lecture well. The percentage score result indicates that for each performance indicator according to student perception there are some aspects that must be maintained and developed by lecturer: 1). Giving apperception at the beginning of lecture, whereas lecturer explain relation of previous topic with topic to be studied. 2). Lecturers use teaching methods that varied in lecturer. 3). Lecturers give students the opportunity to ask questions. 4). Lecturers provide tasks in accordance with the topics that has been taught. 5). Lecturers provide appreciation for students or groups who are able to complete the task well. 6). Lecturers compile test questions in accordance with the topics that have been taught. 7). Lecturers appreciate the opinions or answers of the students, although considered inappropriate. 8). Objective in the assessment, and 9). Lecturers acts as role model for both attitude and behavior. However, there are also some things that must be fixed: many lecturers do not share the exam results to students, lecturers do not discuss the exam, and lecturers do not hold remedial for students who have not completed.
\end{abstract}

Keywords: perception, student, performance, lecturer 


\section{PENDAHULUAN}

Untuk meningkatkan mutu suatu perguruan tinggi tidak luput dari peningkatan mutu bagiannya, oleh karena itu untuk meningkatkan mutu Universitas Mataram khususnya Fakultas Kegutuan dan Ilmu Pendidikan maka harus diupayakan peningkatan mutu program studi yang ada didalamnya salah satunya program studi pendidikan matematika. Peningkatan mutu suatu pendidikan sangat dipengaruhi oleh peningkatan mutu penyelenggaraan proses belajar mengajar. Dengan demikian, peningkatan mutu pendidikan dapat dimulai dengan menganalisis setiap komponen dalam proses belajar mengajar.

Proses belajar mengajar di Perguruan Tinggi melibatkan 3 unsur yang tidak bisa terlepaskan satu sama lain yaitu: (1) dosen; (2) materi perkuliahan; dan (3) mahasiswa. Masing-masing komponen tersebut saling mempengaruhi satu sama lain untuk dapat mencapai tujuan pembelajaran sehingga akan sulit untuk menganalisis komponen-komponen tersebut secara sekaligus. Masing- masing memiliki peranan tersendiri, akan tetapi dosen merupakan komponen multiperan yang sangat mempengaruhi proses penyelenggaraan pendidikan. Hal ini dikarenakan dalam proses belajar mengajar, dosen secara langsung berinteraksi dengan mahsiswa sebagai subjek dan objek belajar. Selain itu, keberhasilan suatu strategi pembelajaran akan tergantung dalam kemampuan dosen dalam merencanakan dan melaksanakan pembelajaran $[1,2]$. Oleh karena itu, dalam rangka meningkatkan mutu pendidikan sebaiknya dimulai dengan menganalisis komponen dosen.

Untuk menganalisis komponen dosen dapat dilakukan melalui penilaian kinerjanya. Melalui penilaian kinerja dosen, dapat dilakukan analisis penguasaan kompetensi dan penerapan pengetahuan serta keterampilan dosen dan menemukan faktorfaktor yang perlu dievaluasi agar dapat diperbaiki ataupun dikembangkan guna menyusun suatu proses pembelajaran yang lebih baik. Dalam pelaksanaannya, penilaian kinerja dosen dapat dilakukan oleh berbagai sumber penilaian seperti mahasiswa, rekan sejawat, atasan sampai penilaian diri sendiri.

Dalam kehidupan sehari-hari, istilah kinerja dikenal sebagai performance atau unjuk kerja. Kinerja adalah cara perseorangan atau kelompok dari suatu organisasi menyelesaikan suatu pekerjaan atau tugas $[3,4]$. Dijelaskan bahwa performance dipandang sebagai suatu proses untuk mencapai hasil kerja. Performance lebih ditekankan kepada upaya atau pelaksanaan kinerja itu sendiri, ketimbang hasil yang diperoleh dari kinerja tersebut. Sebaliknya, kinerja dengan istilah prestasi kerja, yaitu hasil kerja seorang karyawan selama periode tertentu dibandingkan dengan berbagai kemungkinan, misalnya standar, target, atau kriteria yang telah ditentukan lebih dahulu dan telah disepakati bersama [5].

Dalam proses belajar mengajar atau yang sering disingkat pembelajaran, kinerja dosen memikul tanggung jawab utama dalam perubahan mahasiswa, baik dari aspek pengetahuan, keterampilan maupun sikapnya guna membentuk mahasiswa yang berpengetahuan, mampu menyerap dan mengelola berbagai informasi untuk memecahkan masalah yang berkaitan dengan kehidupannya. Proses belajar mengajar diarahkan untuk pengembangan aktivitas mahasiswa dalam belajar sehingga dosen bertugas untuk menciptakan suasana pembelajaran yang baik, mampu menarik minat dan motivasi mahasiswa, menyenangkan, dan juga bermanfaat. Sehingga dalam pelaksanaannya, proses belajar mengajar dijadikan suatu proses dimana mahasiswa diarahkan pada pemahaman konsep yang membantu mahasiswa untuk berpikir dan bertindak secara sistematis, logis, kritis dan kreatif. Oleh karena itu, dalam melangsungkan sebuah pembelajaran, dosen dituntut untuk menjadi dosen yang berkompetensi. Tak hanya sekedar menyampaikan konsep-konsep matematika tetapi juga aplikasi matematika dalam kehidupan seharihari. Kinerja dosen dalam melangsungkan proses belajar mengajar akan optimal apabila dosen memiliki kompetensi dan motivasi yang memadai.

Berdasarkan pemaparan tersebut, dapat diperoleh gambaran bahwa kinerja merupakan upaya yang ditunjukkan oleh seseorang dalam melaksanakan suatu kegiatan, tugas dan tanggung jawabnya serta prestasi atau hasil yang diperoleh melalui upaya tersebut. Sehingga terlihat bahwa konsep kinerja dapat diamati baik dari segi proses misalnya kemampuan dalam melaksanakan tugas maupun dari segi hasil berupa prestasi dan hasil kerja. Dalam kaitannya dengan dosen, kinerja akan tercermin pada kompetensi dosen dalam menjalankan tugasnya dan prestasi kerja yang diperoleh, serta didukung dengan hasil belajar mahasiswa.

Mahasiswa adalah salah satu komponen dalam pembelajaran yang berinteraksi secara langsung dengan dosen. Dalam upaya untuk memperbaiki proses belajar mengajar mahasiswa adalah salah satu unsur yang dapat memberikan penilaian terhadap kinerja dosen. Untuk dapat mengungkapkan penilaiannya mahasiswa dapat memberikan persepsinya terhadap kinerja dosen. Hal senada diungkapkan Desmita, 2012 yaitu Persepsi individu terhadap objek tertentu akan mempengaruhi pikirannya. Artinya, persepsi seseorang akan memungkinkannya untuk memberi penilaian terhadap suatu kondisi stimulus (rangsangan) [6]. Penilaian seseorang terhadap suatu stimulus biasanya dilakukan melalui proses kognitif, yaitu proses mental yang memungkinkan seseorang mengevaluasi, memaknai dan menggunakan informasi yang diperoleh melalui indranya. Ini berarti, meskipun persepsi bergantung pada indra manusia, proses 
kognitif yang ada pada diri manusia akan memungkinkan terjadinya proses penyaringan, perubahan atau modifikasi dari stimulus yang ada.

Berdasarkan uraian di atas, tim penelitian menganggap perlu untuk dilakukan penelitian tentang persepsi mahasiswa program studi pendidikan matematika terhadap kinerja dosen dalam proses perkuliahan. Penelitian ini dilakukan terbatas pada tahun akademik 2015/2016. Penelitian ini bertujuan untuk mengetahui persepsi mahasiswa pendidikan matematika terhadap kinerja dosen dalam proses perkuliahan tahun akademik 2015/2016 dan untuk mengetahui hal-hal yang perlu diperbaiki maupun dikembangkan dalam proses perkuliahan berdasarkan persepsi mahasiswa terhadap kinerja dosen dalam proses perkuliahan tahun akademik 2015/2016.

\section{METODE PENELITIAN}

\section{Desain Penelitian}

Desain penelitian ini adalah penelitian deskriptif. Desain penelitian deskriptif bertujuan untuk menguraikan sifat atau karakteristik dari suatu fenomena tertentu. Penelitian deksriptif menjadi beberapa jenis, salah satunya yaitu analisis kegiatan (activity analysis) [7,8]. Dalam pendidikan, analisis kegiatan dilakukan terhadap pelaksanaan tugas-tugas dan pekerjaan para pengawas, kepala sekolah, guru, konselor pendidikan, laboran, pustakawan, staf administrasi maupun para siswa dan mahasiswa. Analisis kegiatan para pengelola dan pelaksana pendidikan, profesional, semi profesional ataupun tenaga terampil difokuskan pada menganalisis tingkat kinerja dan tingkat keterampilan, kecakapan atau profesionalisme mereka. Sehingga penelitian ini merupakan penelitian deskriptif jenis analisis kegiatan yang bertujuan untuk memberikan gambaran tentang persepsi mahasiswa terhadap kinerja dosen tahun akademik 2015/2016

\section{Variabel Penelitan}

Variabel-variabel penelitian secara garis besar dapat dibedakan ke dalam dua jenis, yaitu variabel bebas atau independent variable, dan variabel tergantung atau dependent variable. Variabel bebas adalah variabel yang kemunculannya menjadi sebab munculnya variabel lain. Adapun variabel tergantung adalah variabel yang kemunculannya diasumsikan sebagai akibat dari adanya variabel sebab. Dalam penelitian ini melibatkan dua variabel yaitu 1) kinerja dosen sebagai variabel bebas 2) persepsi mahasiswa sebagai variabel tergantung.

\section{Instrumen Penelitian}

Alat ukur atau instrumen yang digunakan dalam penelitian ini adalah sebuah angket tertutup, dimana responden tinggal memilih jawaban yang sudah tersedia. Tipe jawaban yang digunakan adalah bentuk check list $(\sqrt{ })$

\section{a. Teknik Penskoran}

Angket dalam penelitian ini menggunakan skala Likert. Jawaban setiap item instrumen yang menggunakan skala Likert mempunyai gradasi dari sangat positif sampai sangat negatif, yang dapat berupa kata-kata antara lain: (1) sangat setuju, setuju, ragu-ragu, tidak setuju (2) selalu, sering, kadangkadang, tidak pernah (3) sangat positif, positif, negatif, sangat negatif (4) sangat baik, baik, tidak baik, sangat tidak baik. Dalam angket bagi mahasiswa, digunakan modifikasi skala Likert bentuk kedua yaitu menjadi semua, sebagian besar, sebagian kecil, tidak ada. Hal ini dimaksudkan agar mengurangi kecenderungan responden memilih jawaban netral dalam mengisi kuesioner. Skor tiap item angket bagi mahasiswa adalah sebagai berikut: Semua Dosen $(\mathrm{SD})=4$, Sebagian Besar Dosen $(\mathrm{SBD})=3$, sebagian Kecil Dosen $(\mathrm{SKD})=2$, Tidak ada Dosen $(\mathrm{TAD})=1$

\section{b. Teknik Analisis Data}

Data tentang persepsi mahasiswa terhadap kinerja dosen dalam proses perkuliahan dianalisis dengan analisis deskriptif kuantitatif yang disajikan dalam tabel. Langkah-langkah analisis data adalah pertama, mencari prosentase jawaban dari responden untuk kinerja dosen dengan menggunakan rumus berikut:

$$
p=\frac{\sum_{i=1}^{n} x_{i}}{S M I} \times 100 \%
$$

Keterangan: $p=$ skor kinerja dosen $(\%) ; x=$ skor yang diperoleh setiap responden; SMI $=$ jumlah skor maksimum ideal responden dimana: SMI $=$ jumlah indikator $\times$ jumlah skala sehingga untuk angket bagi siswa, SMI $=30 \times 4=120$

Kedua, memasukkan hasil prosentase yang diperoleh dari responden untuk setiap item kedalam kategori Penilaian Acuan Patokan (PAP) Kategori yang dimaksud adalah sebagai berikut:

Angka $75 \%<\mathrm{p} \leq 100 \%=$ sangat baik; Angka 50\% $<$ p $\leq 75 \%=$ baik; Angka 25\%

$<\mathrm{p} \leq 50 \%=$ kurang baik; Angka $0 \% \leq \mathrm{p} \leq$ $25 \%=$ tidak baik

\section{HASIL PENELITIAN DAN PEMBAHASAN}

Data yang peroleh dari penelitian ini adalah data dari hasil penyebaran angket. Jumlah mahasiswa yang menjadi responden dalam penelitian ini adalah 120 orang yang tersebar dari mahasiswa semester III, V, VII dan IX. Mahasiswa semester I tidak terpilih untuk menjadi responden, hal ini disebabkan karena mulai tahun akademik 2016/2017 mahasiswa semester I mengikuti program TPB (Tahun Pertama Bersama). Berikut adalah data setelah diolah untuk 
mencari prosentase persepsi mahasiswa terhadap kinerja dosen program studi pendidikan matematika pada proses perkuliahan tahun akademik 2015/2016.

Dari Tabel 1 terlihat bahwa ada 9 item yang berkategori sangat baik dan 21 item berkategori baik. Sedangkan skor kinerja dosen totalnya adalah 69,5\% dengan kategori baik. Dari Tabel 2. terlihat bahwa ada $23,33 \%$ dari jumlah responden yang mempunyai persepsi bahwa kinerja dosen pada program studi pendidikan matematika berkategori sangat baik, $75 \%$ dari jumlah responden yang mempunyai persepsi bahwa kinerja dosen pada program studi pendidikan matematika berkategori baik dan sisanya 1,67\% mempunyai persepsi bahwa kinerja dosen program studi pendidikan matematika berkategori kurang baik.

Tabel 1. Prosentase persepsi mahasiswa pada setiap item penilaian kinerja Dosen

\begin{tabular}{|c|c|c|c|c|c|}
\hline $\begin{array}{l}\text { No. } \\
\text { Item }\end{array}$ & $\begin{array}{c}\text { Skor Kinerja } \\
\text { Dosen }(\%)\end{array}$ & Kategori & No. Item & $\begin{array}{c}\text { Skor Kinerja } \\
\text { Dosen }(\%)\end{array}$ & Kategori \\
\hline 1 & 69 & Baik & 16 & 53 & Baik \\
\hline 2 & 68 & Baik & 17 & 53 & Baik \\
\hline 3 & 76 & Sangat Baik & 18 & 60 & Baik \\
\hline 4 & 60 & Baik & 19 & 71 & Baik \\
\hline 5 & 77 & Sangat Baik & 20 & 64 & Baik \\
\hline 6 & 74 & Baik & 21 & 55 & Baik \\
\hline 7 & 71 & Baik & 22 & 68 & Baik \\
\hline 8 & 74 & Baik & 23 & 78 & Sangat Baik \\
\hline 9 & 87 & Sangat Baik & 24 & 70 & Baik \\
\hline 10 & 75 & Baik & 25 & 71 & Baik \\
\hline 11 & 64 & Baik & 26 & 71 & Baik \\
\hline 12 & 60 & Baik & 27 & 53 & Baik \\
\hline 13 & 85 & Sangat Baik & 28 & 68 & Baik \\
\hline 14 & 77 & Sangat Baik & 29 & 76 & Sangat Baik \\
\hline 15 & 80 & Sangat Baik & 30 & 78 & Sangat Baik \\
\hline & $\begin{array}{l}\text { al Kinerja } \\
\text { sen }\end{array}$ & & & Kateg & Baik \\
\hline
\end{tabular}

Tabel 2. Prosentase Jumlah Responden Berdasarkan Masing - Masing Kategori

\begin{tabular}{lc}
\hline \multicolumn{1}{c}{ Kategori } & Jumlah Responden (\%) \\
\hline Sangat Baik & 23,33 \\
Baik & 75,00 \\
Kurang Baik & 1,67 \\
Tidak Baik & 0,00 \\
\hline
\end{tabular}

Berdasarkan hasil penelitian dapat diketahui bahwa persepsi Mahasiswa Program Studi Pendidikan Matematika FKIP Unram terhadap kinerja dosen dalam proses belajar mengajar tahun akademik 2015/2016 berkategori baik dengan prosentase skor kinerja sebesar 69,5\%. Hal ini berarti bahwa lebih dari $50 \%$ dan kurang dari atau sama dengan $75 \%$ dari jumlah dosen melakukan indikator penilaian kinerja. Akan tetapi walaupun demikian masih banyak hal yang harus dikembangkan atau diperbaiki oleh dosen untuk terus meningkatkan kinerjanya agar proses perkuliahan dapat berlangsung efektif dan efisien.

Dengan memperhatikan skor kinerja pada setiap item indikator kinerja dosen ada 9 item yang berkategori sangat baik yaitu pada item no. 3, 5, 9, 13, 14, 15, 23, 29, dan 30. Hal ini menunjukkan bahwa menurut persepsi mahasiswa, kinerja dosen program studi pendidikan matematika sudah sangat baik dalam beberapa hal, yang berarti bahwa lebih dari $75 \%$ dari jumlah dosen sudah melakukann hal - hal sebagai berikut: 1 . Memberikan apersepsi diawal perkuliahan yaitu dosen menjelaskan kaitan materi sebelumnya dengan materi yang akan dipelajari. 2 . Dosen menggunakan metode mengajar yang berfariasi dalam pekuliahan. 3. Dosen memberi kesempatan kepada mahasiswa untuk bertanya mengenai materi yang belum dipahami. 4. Dosen memberikan tugas yang sesuai dengan materi yang telah diajarkan. 5. Dosen memberikan tambahan nilai bagi mahasiswa atau kelompok yang mampu menyelesaikan tugas dengan baik. 6. Dosen menyusun soal ujian sesuai dengan materi yang telah diajarkan. 7. Dosen mengargai pendapat atau jawaban mahasiswa meskipun dipandang kurang tepat. 8. Dosen bersikap obyektif dalam penilaian, dan 9. Dosen dapat dijadikan contoh baik sikap maupun prilaku sedangkan untuk 21 indikator lainnya berada pada kategori baik yang artinya lebih dari $50 \%$ dan kurang dari atau sama dengan $75 \%$ dari jumlah dosen melakukan indikator - indikator tersebut. 
Berdasarkan prosentase skor kinerja dari setiap indikator terlihat bahwa prosentase yang tertinggi adalah $87 \%$ dengan kategori sangat baik untuk indikator memberi kesempatan kepada mahasiswa untuk bertanya mengenai materi yang belum dipahami sedangkan prosentase terendah adalah $53 \%$ dengan kategori baik untuk tiga indikator yaitu dosen membagikan hasil ujian kepada mahasiswa, dosen membahas soal ujian, dan dosen mengadakan remedial untuk mahasiswa yang belum tuntas.

Berdasarkan prosentase jumlah responden untuk masing-masing kategori, terlihat bahwa untuk kategori sangat baik, baik, dan kurang baik berturutturut adalah 23,33\%, $75 \%$, dan 1,67\%. Artinya ada beberapa mahasiswa yang mempunyai persepsi kurang baik terhadap kinerja dosen pendidikan matematika FKIP Unram tahun akademik 2015/2016. Hal ini disebabkan karena untuk mahasiswa semester III belum terlalu mengenal semua dosen, hal ini disebabkan ada beberapa dosen yang hanya membina mata kuliah di semester IV ke atas sehingga mahasiswa semester III tidak tahu bagaimana dosen tersebut melakukan proses perkuliahan. Tetapi walaupun demikian dari hasil penelitian ini harus diperhatikan untuk terus memperbaiki proses perkuliahan agar lebih baik lagi.

\section{KESIMPULAN}

Berdasarkan hasil penelitian maka dapat disimpulkan bahwa:

1. Persepsi mahasiswa Program Studi Pendidikan Matematika FKIP Unram terhadap kinerja dosen program studi pendidikan matematika FKIP Unram pada tahun akademik 2015/2016 berkategori baik dengan prosentase skor $69,5 \%$. Artinya lebih dari $50 \%$ dan kurang dari atau sama dengan $75 \%$ dari jumlah dosen yang aktif di program studi pendidikan matematika FKIP Unram sudah melaksanakan proses perkuliahan dengan baik.

2. Dalam proses perkuliahan ada beberapa hal yang harus tetap dipertahankan dan terus ditingkatkan oleh dosen - dosen program studi pendidikan matematika FKIP Unram, yaitu: 1). Memberikan apersepsi diawal perkuliahan yaitu dosen menjelaskan kaitan materi sebelumnya dengan materi yang akan dipelajari. 2). Dosen menggunakan metode mengajar yang berfariasi dalam pekuliahan. 3). Dosen memberi kesempatan kepada mahasiswa untuk bertanya mengenai materi yang belum dipahami. 4). Dosen memberikan tugas yang sesuai dengan materi yang telah diajarkan. 5). Dosen memberikan tambahan nilai bagi mahasiswa yang mampu menyelesaikan tugas dengan baik. 6). Dosen menyusun soal ujian sesuai dengan materi yang telah diajarkan. 7). Dosen menghargai pendapat atau jawaban mahasiswa meskipun dipandang kurang tepat. 8). Dosen bersikap obyektif dalam penilaian, dan 9). Dosen dapat dijadikan contoh baik sikap maupun prilaku.

3. Dalam proses perkuliahan hal - hal yang perlu diperhatikan dan diperbaiki oleh para dosen yang ada di program studi pendidikan matematika FKIP Unram adalah sebagai berikut: masih banyak dosen yang tidak membagikan hasil ujian kepada mahasiswa, dosen tidak membahas soal ujian, dan dosen tidak mengadakan remedial untuk mahasiswa yang belum tuntas.

\section{DAFTAR PUSTAKA}

1. Danim, S. (1995). Media komunikasi pendidikan: pelayanan profesional pembelajaran dan mutu hasil belajar (proses belajar mengajar di Perguruan Tinggi). Bumi Aksara.

2. Sani, R. A. (2013). Inovasi pembelajaran. Jakarta: Bumi Aksara.

3. Rai, I Gusti Agung. 2008. Audit Kinerja pada Sektor Publik: Konsep, Praktik, Studi Kasus. Jakarta: Salemba Empat.

4. Fikriadi, F., Rusdiawan, R., \& Wilian, S. (2017). Kontribusi Kinerja Komite Sekolah Dan Kepemimpinan Kepala Sekolah Terhadap Mutu Pembelajaran Di SMAN 1 Tanjung Kabupaten Lombok Utara. Jurnal Ilmiah Profesi Pendidikan, 2(1), 45-54.

5. Cahyono, A. (2012). Analisa Pengaruh Kepemimpinan, motivasi, dan budaya organisasi terhadap kinerja Dosen dan Karyawan di Universitas Pawyatan Daha Kediri. Jurnal Ilmu Manajemen Revitalisasi, 1(1), 283-298.

6. Pramudyo, A. (2010). Analisis faktor-faktor yang mempengaruhi kinerja dosen negeri pada kopertis Wilayah V Yogyakarta. Jurnal Bisnis Teori \& Implementasi, 1(1), 1-11.

7. Uno, H. B., \& Lamatenggo, N. (2012). Teori kinerja dan pengukurannya. Jakarta: Bumi Aksara.

8. Desmita. 2012. Psikologi Perkembangan Peserta Didik. Bandung: PT Remaja Rosdakarya.

9. Slameto. 2010. Belajar dan faktor-faktor yang mempengaruhinya. Jakarta: Rineka Cipta. 